\title{
Unshackling the Church
}

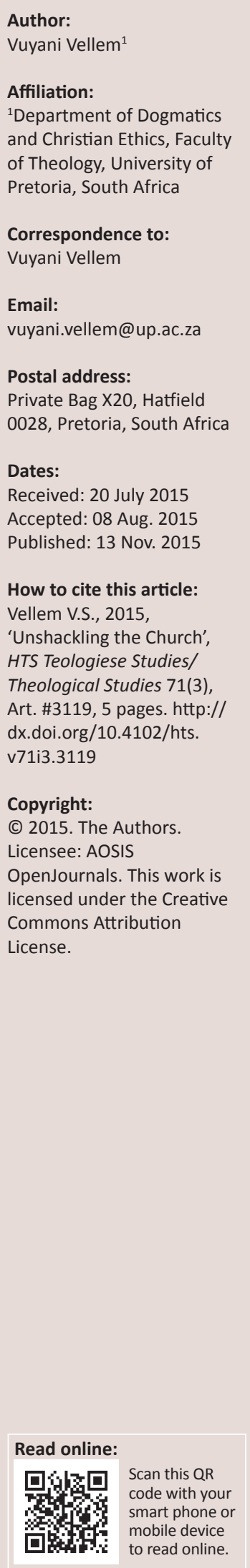

In whose 'order', 'newness' and 'foundation' is ecclesiology based in South Africa? The colonial legacy of pigmentocracy, the cultural domination and annihilation of the indigenous dispensation of black Africans, is not devoid of institutional structures of faith and their historical performance in South Africa. The church is one institution in South Africa that played a crucial role in perpetrating perversities of racial, economic and cultural exclusion with a fetish of its institutional character that is still pervasive and dangerously residual in post-1994 South Africa. By presenting a brief outline of the basics on ecclesiology, the article argues that things remain the same the more things seem to change if the methodological approach to ecclesiology circumvents the edifice and foundations on which the history of ecclesiology in South Africa is built. To unshackle the church, a Black Theology of liberation must begin from and debunk the foundations of models of ecclesiology that are conceived on perverse theological and ideologised forms of faith that have become residually hazardous in South Africa post-1994.

\section{Introduction}

This article argues that in discerning the changes that have taken place in South Africa, change must be subjected to a hermeneutic of suspicion, hence the first section with the subtitle - the more things change, the more they remain the same. The complex and fluid nature of ecclesiology is demonstrated through a brief survey of the classical and historical texts of ecclesiology. The article then proceeds to distinguish models of ecclesiology in South Africa to clarify the choice of a model that can enhance the subversive character of ecclesiology which is indispensable for the quest to unshackle the church.

\section{The more things change, the more they remain the same}

At the Conference of the Trans-Atlantic Roundtable on Religion and Race held at the University of South Africa between 14 and 17 July 2014, Desmond van der Water made an important remark as he was reading his paper: ' $T$ T]he more things change, the more they stay the same'. This paper was later published in Missionalia in 2015. Of course, what Van der Water said is a well-known saying with depth when one looks at the church in South Africa, particularly post-1994. He was reflecting on our progress in South Africa post-1994 and argued in this paper that challenges of racism and exclusion have continued into the post-1994 South African public life. Importantly, from a postcolonial perspective, Van der Water (2015) says:

The reason we still concern ourselves about 'colonialism' and its residue in mission when the era of colonialism seems over is that $[\ldots]$ a 'neo-colonialism' has emerged and permeated every sector of people's lives in the world, without having to invade the physical territory of the colony. (pp. 1-7)

In the context of this article, whilst alert to the approach, Van der Water (2015:1-7) assumes in his analysis of the social struggles of faith in what he dubs 'a time of Black Empowerment', our interest is in the proposals he makes for what he also designates as a postcolonial agenda of mission in this era. Van der Water (2015:11) argues that '[i]t does matter who sets the agenda for postcolonial mission'. Furthermore, he is thankful that Black Theology and other paradigms of liberation have emerged, as theology does not happen in a vacuum, especially in the light of the dominant texts that bear the names of the Global North. He (Van der Water 2015:12) goes on to point to 'a growing - perhaps in some instances grudging - acceptance that theologians are shaped by context' and thus, inevitably, the movement of theological thought away from the captivity of the North would be necessary. ${ }^{1}$ Van der Water (2015:12) makes an important point as he continues to argue that there is 'a fundamental denial' of theologies such as Black Theology of liberation and others. These observations are important for our conversation as this article is written from a Black Theology of liberation perspective, especially its convergence

1.The begrudging acceptance of alternative paradigms is a vexing question for theological discourse in South Africa and the global South; see Vellem (2015:183). 
with postcolonial theory on the residues of colonialism that permeate all spheres of life without necessarily having to invade the physical territories of the previously colonised. In this regard, the question of unshackling the church points us to these residual presences of colonialism in our ecclesiology in South Africa and the Global South.

Having said this, we need to be aware of the fact that postcolonial theory is contested and there are many critical points that have been levelled against this frame of thought. About postcolonial theory, Edward Antonio (2006) says:

There are other objections that have been levelled at postcolonial theory such, for example, as that it is a homogenizing, essentializing and universalising discourse; it is homogenizing because it ignores the manifold variety of colonial histories, essentializing because it regards the identities of all colonial subjects as metaphysically possessed of a single unifying essence and it is universalizing in so far as it proposes a generic representation of colonialism which covers all its instances in all places. (p. 6)

Similar views have been expressed against the liberation paradigm. Antonio dismisses these objections. Antonio (2006:6) argues that there is 'a certain historicity' that makes it implausible to explain the experience of the colonised outside of Europe's encounter. There is a 'before' and an 'after' of colonial time in Africa, he argues.

The anticolonial thrust of postcolonial discourse places it in the history of colonialism; therefore, when Desmond van der Water says, 'the more things change, the more things stay the same', he seems to suggest that the 'end' of and the 'after' of colonial time signifies that whilst there could have been change, sadly things could have nonetheless remained the same, at least if one takes into account the views of those oppressed for centuries. Tinyiko Maluleke (1997:23) makes a similar point, albeit from a different perspective, when he says it is important to interpret change by also identifying those who may benefit from change and those who may not. Maluleke (1997) says:

My main critique of both Mugambi and Villa-Vicencio is in their assumption that the end of the 'cold war' has immediate significance for ordinary Africans and that the so-called 'New World Order' is truly 'new' and truly 'orderly' for Africans. Yet, as Mugambi himself rightly points out, Africa's problems of poverty, war, dictatorships, and American bully-boy tactics are unlikely to decrease. (p. 23)

The reference to Mugambi and Villa-Vicencio is not immaterial for our discussion as they are critiqued for their views on changes that took place after the demise of Apartheid. What is rather more significant though for our discussion is the 'newness' or 'orderliness' of this change as Maluleke points out. Indeed our methodological approach to the question at hand requires to be assessed on how significantly new and orderly these changes are to the victims of centuries of colonialism and the residues of its ecclesiology. All this is said to situate the discussion of this article methodologically. It is important to note that the discussion of the concept 'church' in South Africa is difficult outside the conundrums of colonialism and thus the 'before' and 'after' of colonialism, regardless of the changes that might have taken place. In a nutshell, 'African discourse is a response to Africa's negative encounter with its European other' (Antonio 2006:11); therefore, Black Theology's discourse on the concept 'church' is a response to the negative encounter with the European 'church'. This view shapes the manner in which the subject is approached, namely, the reflection on black ecclesiological discourse as a response to black Africa's negative encounter with the European ecclesiology.

As our conversation is pitched within the framework of Black Theology of liberation, it is important to further clarify that there are affinities between postcolonial theory and the liberation paradigm. We have taken advantage of these insights from these exponents of postcolonial theory, Van der Water and Antonio, to lay the ground for our discussion. We argue first that the more there is change, the more things stay the same. Stated otherwise, we argue that if there is democratic dispensation in South Africa, it is more likely that the church stays the same. There are more permutations to this subliminal text of our conversation: the more there is an upsurge of the gospel of prosperity, the postmodernist culture, for example, the more the church that oppressed the poor stays the same. Our focus is the church that is a response to the denial of African identity, the denial of African history and the totalising violent logic of ontological denial of black Africans by the Western Eurocentric categories and their historical formulations of ecclesiology specifically. This is where we should plot our conversation in terms of the quest of unshackling the church.

There are defects of Christian faith Black Theology of liberation should respond to, including naming, signification, and now the commodification of life resulting from the history of denials black Africans have endured up to this day (cf. Vellem 2013:146-162). The entrapment of black African faith and the black church in such defects calls upon the church in South Africa to move out of the 'mission station', the 'Berlin Conference Zone' and the matrices of neocolonial power manifest in the dominant ideological views of the 21st century, especially the commodification of life. The writer of the introduction of Achebe's work, Things fall apart (1958), Biyi Bandele (2001) makes this point:

Africa was rid of the conquistador. Freedom and its boat had arrived. And out of the freedom boat, almost imperceptible, just behind - some would say hand in hand with freedom itself, stepped memory, the vengeful, unforgiving brigand of all time. 'It is the storyteller,' Achebe has said, 'who makes us what we are, who creates history. The storyteller creates the memory that the survivors must have - otherwise their surviving would have no meaning.' Memory heals, it regenerates. It is an affirming god, a transcendent guide in the ritual of continuity. (p. 4)

In 1994, Apartheid was gone; freedom came with its boat with memories out of which the history of the church from a black perspective can only be told for lasting healing and the regeneration of inspiration for continuity of life together with all South Africans across racial, cultural and religious 
divides. Unshackling the church depends on the story teller. For us it is about the memory of defects that must be healed in the ecclesial rituals of continuity, after freedom and its boat arrived since 1994 .

\section{What is the Church?}

The Greek word ekklesia in the New Testament, which describes the newly found communities that followed the teachings of Jesus Christ immediately suggests the difficulties we face in attempting to understand the concept of the church. This is so because this Greek word seeks to translate the Hebrew concepts and models of community that predate our Christian faith even though it is foundational to this very faith. One only needs to remember that Jesus preached to the Jews and sought to convert them, but no other nations and people before his death on the cross. In addition, one simply has to examine the changes that took place in the first five centuries of the existence of the church in the development of ecclesiology - the Patristic era - to appreciate the complexities associated with ecclesiology; for example, the ultimate relationship of the church with empires when it became the official religious institution of the Roman Empire remains one of the most vexing questions up to this day.

Surely, Paul's epistles also share important information about the nature of the church. Most of the terms we use for leadership and indeed the challenges the church faced are often taken from Paul's writings. The book of Acts focuses on the work of the Holy Spirit, whilst the last book of our canon, Revelation, paints a picture of the church in heavenly courts, and interestingly, a church without a temple: 'I did not see a temple in the city, because the Lord God Almighty and the lamb are its temple' (Rv 21:22). The gospels paint yet another picture.

They seem to suggest that Easter, Ascension and Pentecost gave birth to the church. The implication is that the church is a product of the resurrection of our Lord Jesus Christ. This view is attractive to me. Whilst this attempt at broadly describing the church might not be perfect, all we need to grasp is that to search for the nature of the church is fraught with difficulties and complexities both in the New Testament and in the very first five centuries of the development of ecclesiology. Origen, Justin, Tertullian, Ignatius of Antioch, amongst others, are some of the patriarchs who made important contributions in terms of the understanding of the church in the Patristic era. For this reason, a number of models have often been used to describe what the church is especially because of the classical understanding of the visible and invisible dimensions of the church. Ecclesiology is thus hermeneutical and unavoidably fused with epistemological contestation in so far as the historical attempts at giving expression to the invisible prong of the church go.

From the New Testament and the early church some models of the church are basically common today; for example, we have come to talk about 'the church as the people of God'; 'the church as the fellowship of the Holy Spirit', 'the church as the body of Christ'; 'the church as a building'; 'the church as servant' and 'the church as a sacrament' too. All these are but models. They simply help us to understand or grasp what this church is within the limits of our human understanding. It should be added that it is not simple for one to simply choose one model as the all-be-it of what the church is, as all of them attempt to explain what is surely not easy to define even though there is a possibility of understanding what the church is within our limits of human knowledge. It is not necessary to go through all the stages of the development of ecclesiology in the Middle Ages, the Reformation, the Modern era and so forth, save to punctuate the fact that one should be alert to these historical epochs in the quest to defining or describing what the church is within the limits of human understanding.

We should agree to sum up our basic understanding with the well-known distinction: 'church visible and church invisible', to assert both the possibility of comprehending and yet the incomprehensible nature of the church.

The church is an institution and the church is not an institution; it is a mystery willed by God. This is our classical understanding of the church as Christians. Nonetheless, the church as an institution has had many troubles, the most glaring being the divisions and schisms that continue to bedevil this institution to this day. ${ }^{2}$ In the last century, we all know that the ecumenical movement is a constant reminder that a church disunited is a problem itself to witness, marturia. Therefore, at a deeper level, not a single denomination can claim the whole truth for as long as the church visibly remains divided. From this background, we can examine this concept from our history in South Africa. How did the colonial power model this concept of the church?

\section{Models of ecclesiology in South Africa}

Our reflection on this subject is influenced by some works that have already been published in identifying the models of the church in South Africa. ${ }^{3}$ We need to distinguish between three models of the church: the Settler Model, Missionary Model, and the Struggle Model. The names of these models are self-explanatory. About the Settler Model, we should have in mind the churches that were established by Europeans who settled in our land. The feature of this model is that these churches were meant to serve the Settler communities and their interest. The Missionary model entails churches that were established by the missionaries in black African communities. The last model entails the churches that were established by black Africans as a response to the defects encountered in both the Settler and Missionary church models - the well-known Ethiopian Movement and the African Initiated Churches.

2.1 remember that in one interview with the SABC some years ago, I pleaded with the government to refrain from dividing the church as the church knows it better to divide herself.

3.John de Gruchy (2005) also makes almost similar demarcations in outlining the models of the church in South Africa. 
These models are not suggested as a panacea for the examination of ecclesiological development in South Africa, nor do we have to stretch the use of a model beyond its limits; however, for analytical purposes, one does not see how they can be avoided as pivotal starting points in the archaeology of ecclesiology in South Africa as they are historical. We all know that whilst there have been some benefits from the missionary initiated churches, ipso facto, benefits from the missionary enterprise, the role of Christianity in the conquest and colonisation of black Africans cannot be disputed. Nonetheless, the distinguishing features of these models are identifiable together with their weaknesses and possible strengths. Their historicity cannot be denied and some contours on how they could feed into one another are also easily identified, whilst there are features that must be rejected, such as racism and economic exclusion resulting in class differences between and in the origins of these models.

Ecclesiology in South Africa is thus contested and one simply needs to be transparent about one's assumptions and presuppositions when this subject is discussed. The systematic articulation of African response to Western Christianity came about in the late 1960s. It is this approach that is rooted in the dungeons of colonial oppression that shapes my reflection, inspired by the paradigm of liberation. For example, Cone generally speaking, argues that the church is not bounded by race and class and constructs an ecclesiology that combines Black Power and Theology, ultimately proposing a model of the church as God's suffering people. Gutiérrez argues that the task of the church is to struggle for justice and liberation. The church must be a visible sign of the presence of the Lord in the struggle for liberation. One can read Boff, Segundo, Tutu, Boesak and many others to discern this model. An ecclesiology that springs out of the dungeons of colonial, Apartheid oppression sees the church's role much more differently from the Settler and Missionary Models of ecclesiology. One example is the differentiation of the church in the Kairos Document in relation to the three types of theology identified in this Document, namely State Theology, Church Theology and Prophetic Theology.

Therefore, there is a corresponding model of ecclesiology to these three models of theology identified in the Kairos Document.

\section{The subversive nature of the Church}

Stephen Bevans (2011), writing on the ecclesiological nature of Andrew Walls' works, brings an important point we cannot avoid, namely that the church is in its nature serial. Bevans (2011) writes as follows:

There have been times when Christianity flourished in one place, and then was stamped out or withered, only to spring up in another place with the same vigor but with new questions and insights. Indeed, 'Islam can make a much better claim than Christianity for progressive expansion, for steady numerical increase and geographical growth.' In contrast, the Christian Church possesses a serial nature. No one place or people or culture owns it. This is a subversive idea, because it shatters the complacency of Christians who think that the church is one great triumphal procession toward where we are today. (p. 128)

The church is subversive. The church has subverted a number of challenges in her history, such as the Jewish identity which sought to be the heartland of the church. The church did so to the heartlands of Hellenistic culture, the Roman Empire, and now indeed the modernist Enlightenment paradigms too. In this regard, the emergence of a new church in South Africa could be sought in other heartlands, but for us the heartland of the church in South Africa is the black poor person's lived experience. The Model of the Struggle to which we trace an ecclesiology that speaks to the condition of the black African, is by its very nature a subversive one in the light of the dominant paradigms of ecclesiology - the Settler and Missionary Models.

For some of us it is impossible to imagine the relevance of the church in South Africa without the memory of the miserable the wretched of this world when things fell apart between the white race and the black. It is difficult for one to imagine the church in South Africa without the cultural dispensation of the black Africans and surely the historical dismantlement of the indigenous genius of the historically oppressed. One of the most important factors today is the widely discussed matter of Africa as the heartland of the church in the world. Let us then see if there are aspects that have continued to throttle the church from which the church must indeed be unshackled.

\section{Unshackling the Church}

Allan Boesak (2015:2-3) identifies at length the following foundations of the system of oppression against which the church struggled, as in the Struggle Model:

- Colonialism and its vile legacy, which included slavery, subjugation, dehumanisation, dispossession and generational trauma

- Social Darwinism, expressed in customs, laws and attitudes enshrining white superiority and black inferiority which provided the basis for South Africa's peculiar racist, pigmentocratic societal structures

- Socioeconomic, capitalist exploitation, not exclusively based on race, but also, for example, on gender injustice

- Cultural domination resting on cultural annihilation on the one hand and cultural assimilation on the other, the key being that the culture of the subjugated peoples and groups are always deemed worthless compared to the culture of the dominant groups, and therefore unworthy of consideration and contribution

- Power - psychological, ideological, political and economic power - as well as the power derived from international (white) solidarity and global systems of domination

- A belief in white innocence based on a powerful ideology of white, and in many ways, particularly Afrikaner victimhood

- Violence in all its forms: systemic, structural, ideological and pervasive, and physical violence, guaranteeing and solidifying control 
- And finally, and in South Africa absolutely crucial, ideologised religion (sometimes called civil religion), its belief systems, central to which was the belief in white exceptionalism in general and Afrikaner chosenness in particular with its unique and exclusive covenant with God, and its power in the justification of domination and subjugation.

One could arguably ask if these fundamentals of systemic oppression are still prevalent in South Africa post-1994? From the perspective of Black Theology of liberation the pervasive spirit or fetish of Settler and Missionary Models of ecclesiology is still dominant even to this day despite attempts to deal with these, especially those visible features of the total system based on the foundations cited above. A number of churches in South Africa or even the so-called mainline churches are struggling with their identity and most importantly, their trappings in the muddy foundations of the Settler and Missionary Models that can only gain legitimacy when disentangled from their colonial roots and the foundations of systemic oppression stated above.

In a nutshell, the church must be unshackled from the colonial legacy and its pervasive trauma that remains a ferocious residue in South Africa post-1994. The church must be unshackled from the pigmentocratic structures that have gone on for more than 21 years into our democracy. The church must be unshackled from being an instrument of cultural domination by those who perpetuate the hegemony of ecclesiological insights and theologies that present their culture as normative in the interpretation of the gospel of Jesus including those who grudgingly accept that the heartland of Christianity is now in Africa. The church must be unshackled from its complacency with a life-killing capitalist exploitation, with its attendant cultural and psychological maladies that continue to assimilate, coopt and destroy the cultural and psychological resources on which the previously oppressed have continued to survive. We are obviously employing the fundamentals of oppression taken from Boesak above. We are arguing that of the three models described above, these fundamentals are at the very root of these models and we may add, with the propensity to penetrate even the third Model, the Church of the Struggle. For the public role of the church, ideologised religion in the context of a black led government has become a potential danger for the very foundations of ecclesiology and life in South Africa. The church to conclude this tentative list must be unshackled from false consciousness.

\section{Conclusion}

In this article, three main points have been argued on whose basis a list of the shackles from which the church must be disentangled has been given. Change in South Africa and within the South African ecclesiological landscape is contested and often times those who euphorically celebrate and point to the changes that have taken place in South Africa do so without giving attention to the foundations and pillars upon which racist and exclusive models of ecclesiology are built. Without discerning the newness and order that has come to us, the boat of liberation remains elusive. Unshackling the church remains a methodological question. Straddling the classical view of ecclesiology without the historical models and the experience of oppression, ecclesiology in South Africa remains pie in the sky. To unshackle the church, a subversive model of ecclesiology is the starting point wherever it could be identified. For a Black Theology of liberation, the subversive character of the church is in the memory of the miserable, the condition of blackness.

\section{Acknowledgements Competing interests}

The author declares that he has no financial or personal relationships which may have inappropriately influenced him in writing this article.

\section{References}

Achebe, C., 1958, Things fall apart, Penguin, London.

Antonio, E.P. (ed.), 2006, Inculturation and postcolonial discourse in African Theology, Peter Lang Publishing Incorporated, New York, NY.

Bandele, B., 2001, 'Introduction', in C. Achebe (ed.), Things fall apart, pp. 1-19, Penguin, London.

Bevans, S., 2011, 'Ecclesiology, Andrew F. Walls, and the fortunate subversion of the church', in W.R. Burrows, R.M. Gornik \& J. McLean (eds.), An understanding of world Christianity: The vision and works of Andrew F. Walls, pp. 127-138, Orbis, Maryknoll, NY.

Boesak, A.A., 2015, Kairos, crisis, and global apartheid: The challenge to prophetic resistance, Palgrave MacMillan, New York, NY.

De Gruchy, J., 2005, The struggle of the church in South Africa, Fortress Press, Minneapolis, MN.

Maluleke, T.S., 1997, 'Half a century of African theologies', Journal of Theology for Southern Africa 99, 4-23.

Van der Water, D., 2015, 'Social struggle and faith-based activism in "Black Empowerment"' times: An agenda for postcolonial mission - Sounding the horn on some African perspectives', Missionalia 43(1), 7-22. http://dx.doi. org/10.7832/43-1-79

Vellem, V.S, 2013, "The "native experiment": The formation of the Bantu Presbyterian Church and the defects of faith transplanted on African soil', Missionalia 41(2), 146-162. http://dx.doi.org/10.7832/41-2-11

Vellem, V.S., 2015, 'Black Theology of liberation and the economy of life', The Ecumenical Review 67(2), 177-186. http://dx.doi.org/10.1111/erev.12149 